\title{
The Rennin-Angiotensin-Aldosterone System (RAAS) in Vascular Inflammation and Remodeling
}

\author{
Maricica Pacurari PhD ${ }^{1,2, *}$, Kenneth Ndebele PhD ${ }^{1,2,3}$, Ramzi M. Kafoury PhD ${ }^{1,2}$ and \\ Paul B. Tchounwou, PhD ${ }^{1,2}$
}

${ }^{1}$ Biology Department, ${ }^{2}$ NIH RCMI-Center for Environmental Health, College of Engineering, Science, and Technology, Jackson State University, Jackson, MS, 39217, ${ }^{3}$ Department of Pathology, Harvard Medical School, Beth Israel Deaconess Medical Center, Brookline Ave, Boston, MA 02215

*Correspondence to: Maricica Pacurari PhD, College of Engineering, Science, and Technology, Jackson State University, Jackson, MS, 39217; Email: maricica.pacurari@jsums.edu

Citation: Pacurari M, Ndebele K, Kafoury RM, Tchounwou PB. The Rennin-Angiotensin-Aldosterone System (RAAS) in Vascular Inflammation and Remodeling. Discoveries 2013, Oct-Dec; 1(1): e4. DOI: 10.15190/d.2013.4

\begin{abstract}
The renin-angiotensin-aldosterone system (RAAS) through its physiological effectors plays a key role in promoting and maintaining inflammation. Inflammation is an important mechanism in the development and progression of cardiovoascular diseases (CVD) such as hypertension and atherosclerosis. In addition to its main role in regulating blood pressure and therefore its role in hypertension, RAAS has pro-inflammatory and profibrotic effects at cellular and molecular levels. Blocking RAAS provides beneficial effects for the treatment of cardiovascular and renal diseases. Evidence shows that inhibition of RAAS positively influences vascular remodeling thus improving vascular disease outcomes. The beneficial vascular effects of RAAS inhibition are likely due to decreasing vascular inflammation, oxidative stress, endothelial dysfunction, and positive effects on regeneration of endothelial progenitor cells (EPC). Inflammatory factors such as vascular cell adhesion molecule-1 (ICAM-1), tumor necrosis factor- $\alpha$ (TNF $\alpha$ ), interleukin-6 (IL-6), and C-reactive protein (CRP) have key roles in mediating vascular inflammation, and blocking RAAS negatively modulates the levels of these inflammatory molecules. Some of these inflammatory markers are clinically associated with cardiovascular disease events. More studies are required to establish longterm effects of RAAS inhibition on vascular inflammation, vascular cells regeneration, and
\end{abstract}

cardiovascular disease clinical outcomes. This review presents important information on RAAS's role on vascular inflammation, vascular cells responses to RAAS effectors, and on inhibition of RAAS signaling in the context of vascular inflammation, vascular remodeling, and vascular inflammation-associated CVD. Nevertheless, the review also equates the need to re-think and rediscover new RAAS inhibitors.

\section{Keywords:}

vascular inflammation, vascular remo-deling, rennin - angiotensin - aldosterone system, inhibitors

\footnotetext{
Abbreviations

Angiotensin (ANG); Angiotensin converting enzyme (ACE); Angiotensin receptor blockers (ARB); C-reactive protein (CRP); Cardiovascular disease (CVD); Direct rennin inhibitors (DRI); Endothelial progenitor cells (EPC); Extracellular receptor kinase (ERK); Epidermal growth factor receptor (EGFR); Endothelial nitric oxide synthase (eNOS); Endothelium-derived hyperpolarizing factor (EDHF); Endothelin 1 (ET-1); Interleukin 1 beta (IL-1 $\beta$ ); Interleukin 6 (IL-6); Intracellular cell adhesion molecule 1 (ICAM-1); Insulin growth factor (IGF); Monocytes chemoatractant protein 1 (MCP-1); Monocytes inflammatory protein 1 (MIP-1); Mineralocorticoid receptor antagonist (MRA); Nuclear factor

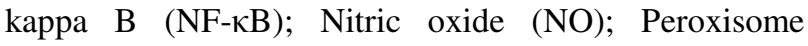
proliferators-activated receptor gamma (PPAR $\gamma$ ); Reninangiotensin-aldosterone system (RAAS); Transforming growth factor beta (TGF $\beta$ ); Tumor necrosis factor alpha (TNF $\alpha)$; Vascular cell adhesion molecule 1 (VCAM-1);
} 


\section{SUMMARY}

1. Renin-angiotensin-aldosterone system (RAAS) and cardiovascular disease

\subsection{RAAS}

2. Inflammation and cardiovascular disease

2.1 Markers of inflammation

2.2 Intercellular adhesion molecules

3. RAAS and vascular inflammation

4. RAAS blockers and vascular inflammation

4.1 Direct renin inhibitors

4.2 Angiotensin converting enzyme inhibitors

4.3 Angiotensin receptors blockers

4.4 Mineralocorticoid receptor antagonists

5. RAAS and vascular remodeling

6. Perspective on RAAS inhibition

\section{Renin-angiotensin-aldosterone system (RAAS) and cardiovascular disease}

The rennin - angiotensin - aldosterone system (RAAS), one of the most important hormonal system, oversees the functions of cardiovascular, renal, and adrenal glands by regulating blood pressure, fluid volume, sodium and potassium balance [1]. The classical RAAS system was discovered more than a century ago, and in 1934 Harry Goldblatt showed a casual link between kidney function and blood pressure [2]. Since then, extensive experimental studies have been undertaken to identify the components of the RAAS, and its role in regulating blood pressure. Abnormal activity of the RAAS leads to the development of an array of cardiovascular diseases (CVD; hypertension, atherosclerosis, left ventricular hyperthrophy), cardiovascular events (myocardial infarction, stroke, congestive heart failure), and renal disease [1]. As early as in 1956, Leonald T. Skeggs suggested the development of drugs to regulate renin-angiotensin-system, and since then an array of inhibitors have been developed. Owing to a higher RAAS signaling pathways complexity than previously thought, halfcentury later, new RAAS inhibitors are still being developed [3]. Indeed, numerous experimental and clinical evidences indicate that pharmacological inhibition of RAAS with angiotensin-converting enzyme inhibitors (ACEIs), angiotensin receptor blockers (ARBs), direct rennin inhibitors (DRIs), and mineraclocorticoid receptor antagonists (MRAs) is effective in treating hypertension, diabetic renal injury, and the results show a reduction in CVD events and heart failure world- wide [1]. This review is focused on the role of RAAS components and its modulatory effects on inflammation and vascular remodeling.

\subsection{RAAS}

Renin, an active proteolytic enzyme, is first synthesized as an inactive preprohormone (prorenin), undergoes subsequent proteolytic changes in the afferent arterioles of renal glomerulus and then is released into circulation [4]. In the circulation, proteolytic and nonproteolytic mechanisms cleave prorenin to the active renin. Active renin acts upon its substrate, angiotensinogen, to generate angiotensin I (Ang I). Ang I is cleaved by angiotensin-converting enzyme (ACE) resulting physiologically active angiotensin II (Ang II). Ang II, the main effector of the RAAS, mediates its effects via type 1 Ang II receptor (AT1R). However, few studies suggest the existence of additional receptors for prorenin and renin in the heart, kidney, liver, and placenta [5]. Other studies suggest the presence of renin receptors in visceral and subcutaneous adipose tissues suggesting a local production of Ang II. Activation of prorenin and renin receptors stimulates mitogen activated kinase (MAPK)/ extracellular signal-regulated kinase (ERK1/2) related signaling pathway [6]. Since the ratelimiting step of RAAS is under the control of renin, the idea of inhibiting renin to suppress RAAS was suggested in the mid 1950s, but the development of rennin inhibitors was a long and difficult process [7]. Likewise, the first oral DRI, aliskiren, was marketed in 2007 for the treatment of hypertension [8]. Another effector of the RAAS, aldosterone, exerts important endocrine functions by regulating fluid volume, sodium and potassium homeostasis, and primarily acting in the renal distal convoluted tubules. Aldosterone mediates genomic and nongenomic effects via mineralocorticoid receptor (MR), AT1R, G-protein-coupled receptor, and epidermal growth factor receptors (EGFR). Downstream effectors of these receptors such as MAPK/ERK1/2 pathway mediate vascular biology and physiology, particularly, vascular remodeling, inflammation, fibrosis, and vascular tone. Aldosterone's cardiopathological effects include myocardial fibrosis and hypertrophy, and vascular remodeling and fibrosis. Production of aldosterone is under the regulation of angiotensin II, hyperkalemia, adrenocroticotropic hormone 
(ACTH), and sodium level [9]. Clinical trials have shown that blocking aldosterone receptors with mineralocorticoid receptor anatagonists (MRA) spironolactone or eplerenone reduces blood pressure, lowers albuminuria, and improves the outcome of patients with heart failure or myocardial infarctions, or cardiovascular complications associated with diabetes mellitus [10]. Aldosterone infusion in an ischemia animal model induces vascular changes via AT1R, since blocking AT1R inhibited aldosterone effects, indicating cross-talk among RAAS components.

The recent discovery and cloning of a new angiotensin converting enzyme, ACE2, has introduced further complexity to RAAS. ACE2 is $42 \%$ homolog to ACE1, and is expressed in the heart, kidney, testis, endothelium of coronary, intrarenal vessels, and renal tubular epithelium [11]. ACE2 is a monopeptidase with enzymatic preference for hydrophobic/basic residues of Ang II C-terminus that leads to the formation of angiotensin II (1-7). Experimental studies show that Ang II (1-7) is a competitor of Ang II, and indeed may have cardio-renal protective effects $[12,13]$ Ang II is also produced by non-ACE enzymes, such as serine protease chymase, which have been found in the heart, vasculatures, and other tissues [14, 15].

\section{Inflammation and cardiovascular disease}

Inflammation plays a key role in the initiation, progression, and development of an array of cardiovascular diseases such as hypertension, atherosclerosis, restenosis after balloon angioplasty, nephropathy, and cardiomyopathy [16]. A typical example of how inflammation underlies the development of cardiovascular disease is atherosclerosis, via the activation of endothelial cells by the inflammatory cytokines. Endothelium dysfunction due to injury by the inflammatory process has been associated with cardiovascular risk factors including hypertension, diabetes mellitus, or obesity [17].

\subsection{Markers of inflammation}

Tumor necrosis factor alpha (TNF $\alpha)$ is a key proinflammatory cytokine regulating the expression of many genes of inflammation, oxidative stress, and anti-apoptotic signaling pathways, virtually, in all types of cells [18]. Aberrant $\mathrm{TNF} \alpha$ signaling leads to the development of pathological conditions, including cardiovascular disease. Therapeutic blocking of TNF $\alpha$ signaling has been proposed for the treatment of several inflammatory diseases, particularly rheumatoid arthritis and bowel disease [18]. TNF $\alpha$ impairs endothelium-dependent nitric oxide (NO) mediated vasorelaxation in coronary arteries or carotid artery via superoxide radical production [19]. Patients with high levels of circulating $\mathrm{TNF} \alpha$ have a greater risk in developing cardiovascular disease [21]. In endothelial cells, $\mathrm{TNF} \alpha$ induces the expression of interleukin-6 (IL$6)$, monocyte chemoatractant protein-1 (MCP-1), and cell adhesion molecules (CAM) [20]. In mice, deletion of TNF $\alpha$ inhibits intimal hyperplasia after carotid artery injury [23], while an increased expression of $\mathrm{TNF} \alpha$ aggravates pulmonary hypertension [24]. TNF $\alpha$ mediated inflammation plays an important role in vascular remodeling. Human carotid artery smooth muscle cells respond to TNF $\alpha$ with increased cell proliferation, whereas inhibition of circulating $\mathrm{TNF} \alpha$ prevents carotid artery post-injury media remodeling and neointima formation in rats [22]. TNFa inhibition has been shown to improve endothelium function via stimulating endothelial cells regeneration [25].

$\mathrm{NF}-\kappa \mathrm{B}$, a pro-inflammatory factor down-stream of $\mathrm{TNF} \alpha$, plays a central role in regulating the expression of vascular inflammatory mediators interleukin-1beta (IL-1 $\beta$ ), interleukin-6 (IL-6), $\mathrm{TNF} \alpha, \mathrm{MCP}-1$ in endothelial cells and other cell types [26]. Activated NF- $\kappa \mathrm{B}$ induces vascular smooth muscle cells proliferation and mediates neointimal hyperplasia after vascular injury [27].

Another marker of inflammation is C-reactive protein (CRP). CRP is considered a hallmark of the acute-phase response and a predictor of cardiovascular event risk [28]. C-reactive protein is mainly produced in the liver [29], but other cell types, such as smooth muscle and endothelial cells, of atherosclerotic arteries show CRP expression [30]. CRP plays a role in mediating vascular disease. In vitro studies show that CRP has proinflammatory and pro-thrombotic effects [31], inhibits endothelial progenitor cell differentiation and function [32], and up-regulates AT1R [33]. CRP activates classical complement signaling cascade, which plays a key role in neointima formation in injured vessels [34]. Circulating CRP levels correlate with several inflammation markers, including inflammatory cytokines, cell adhesion molecules, markers of activated platelets, and white 
cells [35]. All of these inflammation markers are also predictive of coronary artery events [36].

Interleukin-6, a pleiotropic cytokine, regulates many cellular functions, including proliferation and apoptosis. IL-6 plays an important role in inflammation, and modulates the development of several diseases including cardiovascular diseases, such as hypertension and other related disease. High circulating levels of IL-6 are found in hypertensive patients. Type I diabetic rats have high circulating levels of IL-6, and increased blood vessel contractility [37]. IL-6 overexpression in mice induces pulmonary vascular remodeling that is similar to that seen in patients with pulmonary hypertension, and induces pulmonary hypertension via proliferative and antiapoptotic mechanisms [38]. IL-6 also modulates vascular reactivity. Treatment of isolated human blood vessels from various organs with IL-6 results in increased contraction [39]. IL-6 mediates the development of vascular occlusive disease and is a predictor of cardiovascular sudden death [40]. IL-6 effects on vascular system are mediated via NF- $\mathrm{kB}$ signaling, which plays a key role in vascular remodeling. Inhibition of NF- $\kappa \mathrm{B}$ via deletion of I $\mathrm{kBNS}$, a nuclear I $\kappa \mathrm{B}$ regulatory protein of NF- $\mathrm{B}$, reduces intimal hyperplasia after vascular injury in mice via NF-kB-mediated IL-6 production [41].

\subsection{Intercellular adhesion molecules}

Inflammation-mediated injury to endothelium generates a pro-inflammatory signaling cascade and the expression of intercellular adhesion molecule-1 (ICAM-1) and vascular cell adhesion molecule-1 (VCAM-1), both of which recruit blood monocytes to vascular wall, thus perpetuating the release of more cytokines and chemokines at injury site, culminating with the development of vascular disease, such as atherosclerosis. Circulating levels of ICAM-1 and VCAM-1 positively correlate with carotid intima-media ratio [42]. VCAM-1 expression is up-regulated by Ang II in rat aorta, whereas spironolactone, an antagonist of mineralocorticoid receptors, inhibits expression of VCAM-1 and of other inflammatory markers [43]. Treatment of endothelial cells with Ang II upregulates VCAM-1 via oxidative stress and NF- $\kappa B$ activation [44]. High circulating levels of ICAM-1, VCAM-1, and other inflammatory cell adhesion molecules are associated with left ventricle hypertrophy ( $\mathrm{LVH})$ and diastolic dysfunction in aged population. [45]

\section{RAAS and vascular inflammation}

RAAS plays a crucial role in the initiation and maintenance of vascular inflammation and vascular remodeling. Vascular inflammation leads to endothelium dysfunction, and a decreased endothelial function mediates progression of cardiovascular disease. A dysfunctional endothelium is leaky, facilitates migration of inflammatory cells into the vascular wall and stimulates smooth muscle cells proliferation, processes that decrease vascular function and promote development of cardiovascular disease and tissue injury. A dysfunctional endothelium provides a pro-inflammatory environment promoting recruitment and attachment of inflammatory cells, which are well known to play a key role in atherosclerosis. There is increasing evidence indicating a link between hypertension and atherosclerosis via Ang II mediated inflammation. In vivo, acute treatment with Ang II significantly increases leukocytes adhesion in the rat mesenteric arteries [46]. Animal and human studies show Ang II has proinflammatory responses in arteries, heart, and kidney by regulating the expression of cytokines and chemokines. In human vascular smooth muscle cells, Ang II induces NF- $\kappa$ B activation and the expression of IL-6 [47], MCP-1, and TNF $\alpha$ in monocytes [48]. In vivo infusion of Ang II causes increased expression of VCAM-1 in rat aorta via NF- $\kappa \mathrm{B}$ transcriptional activation. Administration of losartan, an AT1R antagonist, inhibits Ang II- induced NF- $\kappa B$ activation and VCAM-1 accumulation [49]. In vitro treatment of rat vascular smooth muscle cells with Ang II upregulates MCP-1, and blockade of AT1R with losartan prevents MCP-1 expression and monocytes migration into vessel wall and other target organs [50]. Although a vasoconstrictor, Ang II induces endothelial damage by inhibiting endothelial cells regeneration. Ang II acts as a second messenger to activate intracellular signaling pathways, such as mitogen-activated protein kinase (MAPK) and AKT, pathways that mediate cell proliferation and inhibit apoptosis, thereby influencing vascular dysfunction [52]. Ang II plays a significant role in the initiation and progression of atherogenesis, an inflammation mediated process. In injured arteries, Ang II provides a positive feedback loop in vascular 
inflammation via recruitment of inflammatory cells, which then produce more Ang II, therefore perpetuating vascular inflammation [1]. Ang II is a potent pro-oxidant. Ang II induces the production of superoxide anions and activates the pro-oxidant $\mathrm{NADH} / \mathrm{NADPH}$ signaling [53]. Ang II-mediated oxidative stress reduces nitric oxide (NO) level, and activates redox sensitive genes, particularly cytokines, adhesion molecules, and matrix metalloproteinases [54]. Ang II is also a pro-fibrotic factor. Chronic infusion of mice with Ang II results in increased blood pressure, infiltration of inflammatory cells into myocardium, and cardiac fibrosis [55]. In rat cardiomyocytes, Ang II induces calcium signals $(\mathrm{Ca} 2+)$, and oxidative stress, which cooperatively induce cardiomyocytes hypertrophy [56]. Chronic treatment of rat aortic smooth muscle cells with Ang II induces cell hypertrophy by increasing protein synthesis [57]. AngII-treated rat cardiac fibroblasts display increased expression of focal adhesion kinases (FAK) and integrins, whereas cardiac myocytes express high levels of cfos, EGFR1, TGF- $\beta$, and extracellular matrix proteins $(109,110)$. Inflammation mediates endothelial injury, which alters endothelial cell architecture so that the endothelium becomes dysfunctional. It has been shown that a dysfunctional endothelium is directly associated with hypertension and atherosclerosis [17]. A functional endothelium is a key regulator of NO release, and loss of NO bioavailability is associated with high level of Ang II via oxidative stress. Although development of atherosclerosis is a multifactorial complex process, interaction between endothelial dysfunction and oxidative stress plays an important role in atherosclerotic process. Increased oxidative stress within the vascular wall is a hallmark of vascular disease, such as atherosclerosis, hypertension, and diabetes. Indeed, high level of superoxide is an important factor in atherosclerosis initiation by recruitment of inflammatory cells and endothelial dysfunction. Total genetic deletion of NADPH oxidase subunit Nox2 in mice results in significant decrease of aortic atherosclerosis [58]. Blocking RAAS with valsartan in combination with fluvastatin (a statin) in atherosclerosis mouse model, the apolipoprotein E (ApoE-/-) null mice, reduces the level of atherosclerotic lesions, superoxide anion, and the expression level of MCP-1 and ICAM-1, indicating that blocking inflammation and oxidative stress has beneficial effects on endothelium [59]. Indeed, clinical studies show a reduction in cardiovascular events beyond lowering blood pressure, such as positively altering endothelium/vascular wall structure, which in turn mediates reduction of cardiovascular disease. Several RAAS inhibitors such as ACEI ramipril and ARB losartan improve endothelial activity and vascular function by increasing NO bioavailability [17]. NO has protective effects on cardiovascular and renal systems. NO effects on the vasculature are numerous, from inducing vasodilation of all types of blood vessels to inhibiting platelet aggregation and adhesion or leukocytes adhesion to endothelium. Furthermore, NO inhibits DNA synthesis, mitogenesis, vascular smooth muscle cells proliferation, and counteracts oxidative stress [60]. NO bioavailability depends on the activity of eNOS, and a diminished eNOS activity is associated with essential hypertension [60].

The proinflammatory and profibrotic effects of the RAAS are also mediated by aldosterone. Aldosterone plays a role in organ fibrosis and tissue ischemia, and in conjunction with macrophages induces cardiac fibrosis [61]. Aldosterone promotes insulin resistance and vascular remodeling, influencing the development of atherosclerosis [62]. In vascular smooth muscle cells, aldosterone alters insulin signaling by up-regulating the expression of insulin-like growth factor-1 receptor (IGF1R) and hybrid receptor, and modulates membrane structure via tyrosine kinase receptors [63]. Chronic infusion of aldosterone induces oxidative stress in rat aorta, and MR antagonist spironolactone reduces reactive oxygen species generation [63]. Animal studies also indicate an association between aldosterone and decreased NO synthesis and endothelial progenitor cells (EPC) via oxidative stress and low levels of VEFGR2 [64]. NO plays a key role in vascular homeostasis through its effects on endothelial and smooth muscle cells. In endothelial cells, NO potentiates VEFG mitogenic effects thereby stimulating endothelial cells proliferation. In VSMC, NO limits their proliferation and migration [65]. In addition to RAAS present in systemic circulation and its production in local tissues, there are also reports on the identification of an intracellular RAAS in certain cell types such as hepatoma cells [66], renal cortical cells [67], or adrenal medullary chromaffin, and pituitary glandular cells [68]. Human and rat adrenal cortical 
cells stimulated with Ang II produce aldosterone via AT1R-upregulation of cytochrome P450 oxidase B2 and increased level of hydrogen peroxide, whereas pretreatment with losartan and antioxidants abrogates Ang II effects [69]. As shown in Figure 1, AngII, the master cytokine, $\mathrm{TNF} \alpha$, and aldosterone, induce the expression of a myriad of molecular effectors of signaling pathway associated with vascular inflammation and remodeling, fibrosis, and oxidative stress. Several molecular molecules such as ERK1/2 and NADPH are also activated by AngII and aldosterone and activate NF- $\mathrm{\kappa B}$-dependent signaling in the absence of TNF $\alpha$, cross-talk that indicates the complexity of RAAS effectors role in mediating vascular inflammation and remodeling (Figure 1). Moreover, the cross talk between AngII and aldosterone indicates the intricacy of the RAAS system on cardiovascular system pathology.

\section{RAAS blockers and vascular inflammation}

Blocking RAAS signaling either with ACEIs which inhibit the formation of angiotensin, or ARBs which block angiotensin receptors, or DRIs which inhibit the renin-angiotensinogen reaction, or MRAs which block aldosterone, alone or in combinations, reduces mortality and morbidity in diabetes, hypertension, atherosclerosis, heart failure, and stroke [70]. The multiple biological and physiological effects as a result of RAAS inhibitors are summarized in Figure 2 and include decreased inflammation, vascular remodeling, and fibrosis, oxidative stress, increased endothelial function and nitric oxide, and maintenance of bradykinin, and endothelium-derived hyperpolarizing factors (EDHF), which contribute to maintenance of vascular tone. However, blockade of the RAAS at one level is not highly effective to treat hypertension, therefore blocking RAAS at multiple levels seems to provide clinical efficacy for the treatment of hypertension and other forms of cardiovascular disease, including atherosclerosis [70].

\subsection{Direct Renin Inhibitors (DRIs)}

DRIs block RAAS by inhibiting renin enzymatic activity. A recently approved DRI, aliskiren, is an oral direct renin inhibitor that lowers blood pressure by blocking the rate-limiting step of the RAAS. In a randomized double-blinded trial study, Andersen et al. [71], and others [72] reported that aliskirenbased therapy lowered blood pressure (BP), and plasma renin activity (PRA), and the effects persisted over four weeks, suggesting long term effects of aliskiren on renin activity. However, plasma renin activity can be increased by ACEIs or ARB, therefore combination of aliskiren with an ACEIs or ARBs has been considered as a preferred option of treatment of hypertension, congestive heart failure, and chronic kidney disease [73]. Aliskiren has beneficial effects on endothelium. In patients with type I diabetes, aliskiren improved endothelial function independently of lowering blood pressure. In an atherosclerosis transgenic mouse model, aliskiren alone or in combination with atorvastatin inhibited atherosclerosis development and plaque progression via decreasing monocytes adhesion and MCP-1 levels [74].

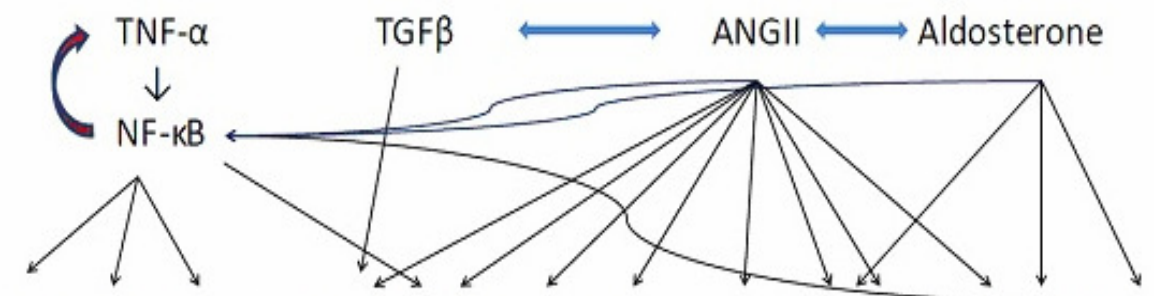

IL-1 $\beta$ IL-6 MCP-1 ECM c-fos FAK Integrins OPN CAM ET-1 ERK1/2 NADPH
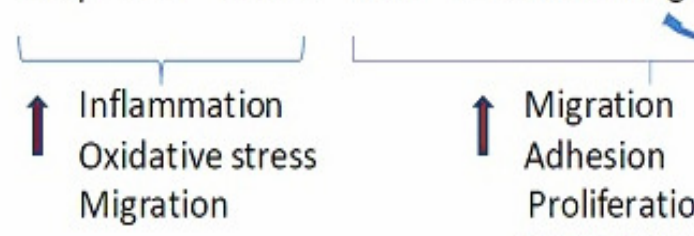

Proliferation

Remodeling

Inflammation

Growth
Figure 1:

Schematic representation of various molecular factors activated by RAAS effectors and cross-talk between RAAS effectors molecular factors involved in signaling pathways with role in vascular inflammation and remodeling. Abbreviations: single arrow: increased expression or stimulation. 
In eNOS deficient mice, aliskiren prevented cardiac hypertrophy, inflammation, coronary artery remodeling, and vascular intimal hyperplasia, and even greater effects were found in combination with valsartan. Mechanistically, aliskiren and valsartan combination downregulates NADPH oxidase activity, therefore attenuates oxidative stress [60], which plays a key role in initiating the development of vascular inflammation and cardiovascular disease.

\subsection{Angiotensin Converting Enzyme Inhibitors (ACEIs)}

The use of ACEIs is an effective conventional treatment of hypertension, reducing left ventricular hypertrophy, therefore improving $\mathrm{CV}$ outcomes [75]. ACEIs treatment of patients with a dysfunctional endothelium caused by various pathological conditions improve endothelial functions measured by brachial flow mediated vasodilation (FMD) [76]. Mechanistically, ACEIs improve endothelium function by increasing NO level via blocking bradykinin degradation, and inhibit the production of endothelin-1 (ET-1), and Ang II by endothelium [77]. Maintaining bradykinin level has an additive effect on endothelium by increasing the level of prostacyclin [78], and endothelium-derived hyperpolarizing factor (EDHF) [79], both of which induce vasodilation, and inhibit vascular smooth muscle cells proliferation and platelet adhesion [77].

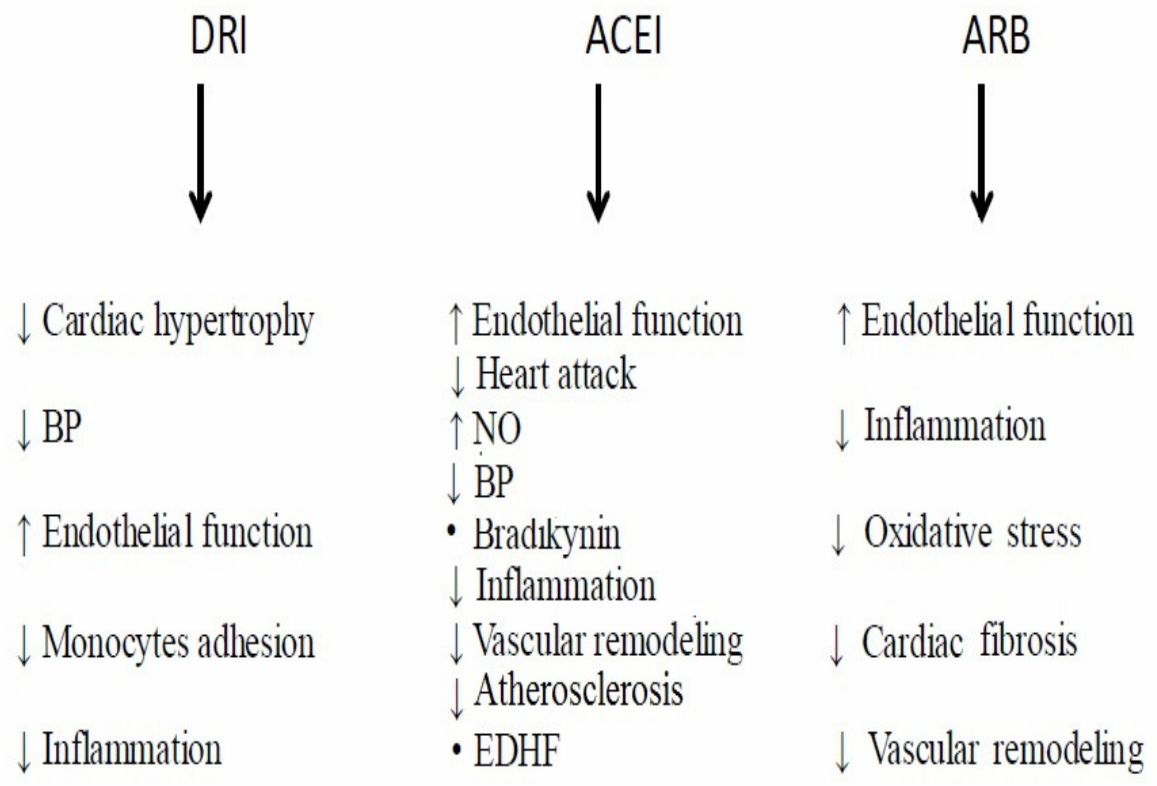

\subsection{Angiotensin Receptors Blockers (ARBs)} Blockade of RAAS with ARBs has been shown to reduce inflammation and to improve endothelial function. In vitro and in vivo studies demonstrate that anti-inflammatory effect of ARB candesartan is through the suppression of the inflammatory receptors toll-like receptor 2 and 4 (TLR2 and TLR4) [17]. Indeed, TLRs have been implicated in development and progression of cardiovascular disease. In animal models of hypertension, TLR4 contributes to blood pressure regulation and small resistance arteries vasoconstriction [80]. In hypertensive patients, ARB irbesartan has been shown to improve endothelial function and vascular reactivity, and to reduce the levels of CRP, ICAM1, IL-6, and oxidative stress marker 8-isoprostane [81]. It is well known that oxidative stress plays an important role in mediating endothelium dysfunction. Use of valsartan has been shown to prevent the formation of reactive oxygen species (ROS), and to suppress the activity of NF- $\kappa \mathrm{B}$, a transcription factor that regulates the expression of inflammatory cytokines and cell adhesion molecules, all of which contribute to development of vascular inflammation and of vascular events [82]. In vitro and in vivo studies have shown that ARB olmesartan inhibits Ang II-induced aortic vascular smooth muscle cells migration, therefore prevents vascular remodeling [83].

\section{Figure 2:}

Schematic representation of RAAS inhibitors on cardiovascular function. Angiotensin converting enzyme inhibitors (ACEI); type 1 Ang II receptor blockers (ARB); blockers (MRB); direct rennin inhibitors (DRI). Thick arrow: stimulation; thin arrow: increased or decreased; bullet: no change 
Use of ARBs in patients with type 2 diabetes mellitus or with stable coronary artery disease increases the number of cardioprotective and endothelial progenitor cells $[84,85]$.

ARBs exert beneficial effects for the treatment of coronary disease and atherosclerosis. Lorsartan treatment improves flow-mediated coronary artery disease in patients with atherosclerosis and endothelial function via NO bioavailability.

\subsection{Mineralocorticoid receptor antagonists}

Dysregulated mineralocroticoid system signaling influences hypertension, atherosclerosis, and cardiac failure independent of renal MR actions on blood pressure [86]. Aberrantly activated MR negatively modulates endothelium function in patients with cardiovascular risk factors and disease. MR are present in vascular smooth muscle cells, endothelial cells, and cardiomyocytes [87]. Activation of MR induces oxidative stress [88], inhibits vascular relaxation, and induces vascular inflammation, fibrosis, and remodeling [63]. Aldosterone-activated MR in human endothelial cells (EC) induces the expression of inflammatory factor ICAM-1 and leukocytes-EC adhesion, and blocking MR with spironolactone inhibits aldosterone-mediated effects on EC [88]. Aldosterone impairs EPC differentiation, migration, and proliferation, whereas pharmacological inhibition or genetic manipulation rescues EPC functions [89, 90]. Aldosterone antagonist spironolactone improves endothelium-dependent vasodilatation via inhibition of $\mathrm{NAD}(\mathrm{P}) \mathrm{H}$ oxidase pathway [90]. Blocking aldosterone signaling also improves heart muscles proliferation and arterial wall remodeling, endothelial function, and $\mathrm{NO}$ synthesis [61]. Many clinical studies have shown that pharmacological inhibition of MR decreases the incidence of heart attack, stroke, and mortality in addition to lowering blood pressure [87]. Most recent studies also show additional benefits from blockade of aldosterone signaling, particularly decreased inflammation, reduced cardiovascular remodeling, and a reduction of atherosclerosis [61].

\section{RAAS and vascular remodeling}

Ang II also induces vascular remodeling, thrombosis, and plaques rupture [51, 91]. Ang II mediated vascular remodeling takes place via the expression of autocrine growth factors basic fibroblast growth factor (bFBS), transforming growth factor- $\beta 1$ (TGF- $\beta 1$ ), and insulin growth factor (IGF) [92]. Vascular remodeling mediated by Ang II is due to increased vascular cell migration, and modification of extracellular matrix composition [83, 93]. Changes in the structure and function of blood vessels, especially in small resistance blood vessels, potentiate the complications of hypertension. Moreover, remodeling of small blood vessels occurs before left ventricular hypertrophy, carotid artery intima-media thickening, or increases microalbuminuria levels. Indeed, a smaller lumen and external diameter of small resistance arteries is seen in patients with hypertension [94]. Changes in the function of small arteries are associated with decreased levels of vasodilators and increased sensitivity to Ang II and related signal transduction pathways.

In addition to its role in hypertension, the reninangiotensin-aldosterone system also plays an important role in mediating vascular remodeling in neointimal hyperplasia after angioplasty and atherosclerosis [95-97]. Ang II is also a growth factor that regulates cell proliferation and differentiation, hypertrophy and apoptosis. In vascular remodeling, Ang II-induced remodeling effects are due to vascular smooth muscle cells proliferation and hypertrophy. The Ang II growth effects, proliferation vs hypertrophy are dependent on cell type and cell-cycle regulated genes. For example, Ang II exerts hypertrophic effect on cardiomyocytes via TGF $\beta 1$ mediated signaling, and blockade of TGF $\beta 1$ receptor abrogates Ang IImediated cardiomyocytes hypertrophy [98]. In myocardial infarction model (MI), ARB, telmisartan, inhibits cardiac remodeling by reducing cardiomyocytes hypertrophy and fibrosis via an anti-inflammatory effect and activation of peroxisome proliferators-activated receptor gamma (PPAR $\gamma)$ [99]. The role of systemic and local reninangiotensin system in vascular remodeling diseases, such as atherosclerosis and neointima hyperplasia after angioplasty, is well established [100]. Ang II/AT1R activation within vascular tissue leads to accumulation of inflammatory cells, fibrosis, and migration of vascular smooth muscle cells [101]. Blocking of Ang II signaling via ACEIs or ARBs have been shown to inhibit Ang II-mediated endothelial dysfunction and atherosclerosis [102], and ARBs efficiently inhibited vascular remodeling and neointimal hyperplasia after vascular injury 
[103, 104]. Indeed, ARB telmisartan has been shown to suppress neointimal hyperplasia after heart transplant in a mouse model, suggesting that telmisartan might provide positive effects in preventing graft rejection [105]. ARB lorsartan has been shown to decrease intima:media ratio of carotid artery or result in arterial resistance in hypertensive patients, and to prevent the production of TGF $\beta$, a known mediator of Ang II [106, 107]. Aldosterone plays a key role in cardiac fibrosis and remodeling via direct effects on collagen synthesis and deposition in the cardiac interstitium. Use of spironolactone in a rat model of myocardial fibrosis prevents myocardial fibrosis [108]. Therefore, all these results prove that blocking RAAS signaling positively regulates vascular remodeling, and vascular inflammation (Fig. 2).

\section{Perspective on RAAS inhibition}

Although RAAS system has been studied for more than a century, new experimental and clinical evidences suggest that the physiology of RAAS is complex and multifactorial, and new or on-going research will provide a better understanding on RAAS physiology. For example, the current understanding on how the interactions between Ang II and aldosterone regulate deleterious cellular processes indicates the intricacy of RAAS signaling and provides the basis for blocking RAAS at different levels (Fig. 2). Moreover, identifying novel targets/effectors of the RAAS system perhaps will provide the basis for the development of novel therapeutic strategies aimed at preventing vascular inflammation and remodeling, therefore improving the outcome of vascular disease.

\section{Acknowledgements \& Conflict of interest}

This research was financially supported by a grant from National Institutes of Health (Grant No. G12MD007581) through the RCMI-Center for Environmental Health at Jackson State University. There is no conflict of interest.

\section{References}

1. Ferrario CM, Strawn WB: Role of the reninangiotensin-aldosterone system and pro-inflammatory mediators in cardiovascular disease. Am $J$ Cardiol 2006;98:121-128.

2. Goldblatt H, Lynch J, Hanzal RF, Summerville WW: Studies on experimental hypertension : I. The production of persistent elevation of systolic blood pressure by means of renal ischemia. J Exp Med 1934;59:347-379.
3. Fyhrquist F, Saijonmaa O: Renin-angiotensin system revisited. J Intern Med 2008;264:224-236.

4. Pimenta E, Oparil S: Role of aliskiren in cardio-renal protection and use in hypertensives with multiple risk factors. Ther Clin Risk Manag 2009;5:459-464.

5. Nguyen G, Delarue F, Burcklé C, Bouzhir L, Giller T, Sraer JD: Pivotal role of the renin/prorenin receptor in angiotensin ii production and cellular responses to renin. $J$ Clin Invest 2002;109:1417-1427.

6. Huang Y, Noble NA, Zhang J, Xu C, Border WA: Renin-stimulated tgf-betal expression is regulated by a mitogen-activated protein kinase in mesangial cells. Kidney Int 2007;72:45-52.

7. Staessen JA, Li Y, Richart T: Oral renin inhibitors. Lancet 2006;368:1449-1456.

8. Brown MJ: Aliskiren. Circulation 2008;118:773-784.

9. Quinn SJ, Williams GH: Regulation of aldosterone secretion. Annu Rev Physiol 1988;50:409-426.

10. Gustafsson F, Azizi M, Bauersachs J, Jaisser F, Rossignol P: Targeting the aldosterone pathway in cardiovascular disease. Fundam Clin Pharmacol 2011

11. Donoghue M, Hsieh F, Baronas E, Godbout K, Gosselin M, Stagliano N, Donovan M, Woolf B, Robison $\mathrm{K}$, Jeyaseelan R, Breitbart RE, Acton S: A novel angiotensin - converting enzyme - related carboxypeptidase (ace2) converts angiotensin i to angiotensin 19. Circ Res 2000;87:E1-9.

12. Zhong J, Guo D, Chen CB, Wang W, Schuster M, Loibner H, Penninger JM, Scholey JW, Kassiri Z, Oudit GY: Prevention of angiotensin ii-mediated renal oxidative stress, inflammation, and fibrosis by angiotensin-converting enzyme 2. Hypertension 2011; 57:314-322.

13. Ferrario CM: Angiotensin-converting enzyme 2 and angiotensin-(1-7): An evolving story in cardiovascular regulation. Hypertension 2006;47:515-521.

14. Richard V, Hurel-Merle S, Scalbert E, Ferry G, Lallemand F, Bessou JP, Thuillez C: Functional evidence for a role of vascular chymase in the production of angiotensin ii in isolated human arteries. Circulation 2001;104:750-752.

15. Urata H, Strobel F, Ganten D: Widespread tissue distribution of human chymase. J Hypertens Suppl 1994;12:S17-22.

16. Tracy RP: Inflammation in cardiovascular disease: Cart, horse, or both? Circulation 1998;97:2000-2002.

17. Mason RP: Optimal therapeutic strategy for treating patients with hypertension and atherosclerosis: Focus on olmesartan medoxomil. Vasc Health Risk Manag 2011;7:405-416.

18. Parameswaran N, Patial S: Tumor necrosis factor- $\alpha$ signaling in macrophages. Crit Rev Eukaryot Gene Expr 2010;20:87-103.

19. Gao X, Belmadani S, Picchi A, Xu X, Potter BJ, Tewari-Singh N, Capobianco S, Chilian WM, Zhang C: Tumor necrosis factor-alpha induces endothelial 
dysfunction in lepr(db) mice. Circulation 2007;115:245254.

20. Russo G, Leopold JA, Loscalzo J: Vasoactive substances: Nitric oxide and endothelial dysfunction in atherosclerosis. Vascul Pharmacol 2002;38:259-269.

21. Pelisek J, Rudelius M, Zepper P, Poppert H, Reeps C, Schuster T, Eckstein HH: Multiple biological predictors for vulnerable carotid lesions. Cerebrovasc Dis 2009;28:601-610.

22. Lambert CM, Roy M, Meloche J, Robitaille GA, Agharazii M, Richard DE, Bonnet S: Tumor necrosis factor inhibitors as novel therapeutic tools for vascular remodeling diseases. Am J Physiol Heart Circ Physiol 2010;299:H995-1001.

23. Zimmerman MA, Selzman CH, Reznikov LL, Miller SA, Raeburn CD, Emmick J, Meng X, Harken AH: Lack of tnf-alpha attenuates intimal hyperplasia after mouse carotid artery injury. Am J Physiol Regul Integr Comp Physiol 2002;283:R505-512.

24. Fujita M, Shannon JM, Irvin CG, Fagan KA, Cool C, Augustin A, Mason RJ: Overexpression of tumor necrosis factor-alpha produces an increase in lung volumes and pulmonary hypertension. Am J Physiol Lung Cell Mol Physiol 2001;280:L39-49.

25. Krasinski K, Spyridopoulos I, Kearney M, Losordo DW: In vivo blockade of tumor necrosis factor-alpha accelerates functional endothelial recovery after balloon angioplasty. Circulation 2001;104:1754-1756.

26. Han Y, Runge MS, Brasier AR: Angiotensin ii induces interleukin-6 transcription in vascular smooth muscle cells through pleiotropic activation of nuclear factor-kappa b transcription factors. Circ Res 1999;84:695-703.

27. Landry DB, Couper LL, Bryant SR, Lindner V: Activation of the nf-kappa $b$ and $i$ kappa $b$ system in smooth muscle cells after rat arterial injury. Induction of vascular cell adhesion molecule-1 and monocyte chemoattractant protein-1. Am J Pathol 1997;151:10851095 .

28. von Känel R, Mills PJ, Mausbach BT, Dimsdale JE, Patterson TL, Ziegler MG, Ancoli-Israel S, Allison M, Chattillion EA, Grant I: Effect of alzheimer caregiving on circulating levels of c-reactive protein and other biomarkers relevant to cardiovascular disease risk: A longitudinal study. Gerontology 2011

29. Hurlimann J, Thorbecke GJ, Hochwald GM: The liver as the site of c-reactive protein formation. J Exp Med 1966;123:365-378.

30. Calabró P, Willerson JT, Yeh ET: Inflammatory cytokines stimulated c-reactive protein production by human coronary artery smooth muscle cells. Circulation 2003;108:1930-1932.

31. Pasceri V, Willerson JT, Yeh ET: Direct proinflammatory effect of c-reactive protein on human endothelial cells. Circulation 2000; 102:2165-2168.
32. Verma S, Kuliszewski MA, Li SH, Szmitko PE, Zucco L, Wang CH, Badiwala MV, Mickle DA, Weisel RD, Fedak PW, Stewart DJ, Kutryk MJ: C-reactive protein attenuates endothelial progenitor cell survival, differentiation, and function: Further evidence of a mechanistic link between c-reactive protein and cardiovascular disease. Circulation 2004;109:2058-2067. 33. Wang CH, Li SH, Weisel RD, Fedak PW, Dumont AS, Szmitko P, Li RK, Mickle DA, Verma S: C-reactive protein upregulates angiotensin type 1 receptors in vascular smooth muscle. Circulation 2003;107:17831790.

34. Hage FG, Oparil S, Xing D, Chen YF, McCrory MA, Szalai AJ: C-reactive protein-mediated vascular injury requires complement. Arterioscler Thromb Vasc Biol 2010;30:1189-1195.

35. Libby P, Theroux P: Pathophysiology of coronary artery disease. Circulation 2005;111:3481-3488.

36. Danesh J, Muir J, Wong YK, Ward M, Gallimore JR, Pepys MB: Risk factors for coronary heart disease and acute-phase proteins. A population-based study. Eur Heart J 1999;20:954-959.

37. Tang WB, Zhou YQ, Zhao T, Shan JL, Sun P, Yang TT, Chang XW, Li S, Wang PS, Xie DP: Effect of interleukin-6 (il-6) on the vascular smooth muscle contraction in abdominal aorta of rats with streptozotocin-induced diabetes. Chin $J$ Physiol 2011;54:318-323.

38. Steiner MK, Syrkina OL, Kolliputi N, Mark EJ, Hales CA, Waxman AB: Interleukin-6 overexpression induces pulmonary hypertension. Circ Res 2009; 104:236-244.

39. Iversen PO, Nicolaysen A, Kvernebo K, Benestad HB, Nicolaysen G: Human cytokines modulate arterial vascular tone via endothelial receptors. Pflugers Arch 1999;439:93-100.

40. Empana JP, Jouven X, Canouï-Poitrine F, Luc G, Tafflet M, Haas B, Arveiler D, Ferrieres J, Ruidavets JB, Montaye M, Yarnell J, Morange P, Kee F, Evans A, Amouyel P, Ducimetiere P: C-reactive protein, interleukin 6 , fibrinogen and risk of sudden death in european middle-aged men: The prime study. Arterioscler Thromb Vasc Biol 2010;30:2047-2052.

41. Niida T, Isoda K, Kitagaki M, Ishigami N, Adachi T, Matsubara O, Takeda K, Kishimoto T, Ohsuzu F: Ikbns regulates interleukin- 6 production and inhibits neointimal formation after vascular injury in mice. Cardiovasc Res 2012

42. Rohde LE, Lee RT, Rivero J, Jamacochian M, Arroyo LH, Briggs W, Rifai N, Libby P, Creager MA, Ridker PM: Circulating cell adhesion molecules are correlated with ultrasound-based assessment of carotid atherosclerosis. Arterioscler Thromb Vasc Biol 1998; 18:1765-1770.

43. Neves MF, Amiri F, Virdis A, Diep QN, Schiffrin EL, Hypertension CMRGo: Role of aldosterone in 
angiotensin ii-induced cardiac and aortic inflammation, fibrosis, and hypertrophy. Can J Physiol Pharmacol 2005;83:999-1006.

44. Pueyo ME, Gonzalez W, Nicoletti A, Savoie F, Arnal JF, Michel JB: Angiotensin ii stimulates endothelial vascular cell adhesion molecule-1 via nuclear factorkappab activation induced by intracellular oxidative stress. Arterioscler Thromb Vasc Biol 2000;20:645-651.

45. Masiha S, Sundström J, Lind L: Inflammatory markers are associated with left ventricular hypertrophy and diastolic dysfunction in a population-based sample of elderly men and women. J Hum Hypertens 2012

46. Alvarez A, Cerdá-Nicolás M, Naim Abu Nabah Y, Mata M, Issekutz AC, Panés J, Lobb RR, Sanz MJ: Direct evidence of leukocyte adhesion in arterioles by angiotensin ii. Blood 2004;104:402-408.

47. Kranzhöfer R, Schmidt J, Pfeiffer CA, Hagl S, Libby $\mathrm{P}$, Kübler $\mathrm{W}$ : Angiotensin induces inflammatory activation of human vascular smooth muscle cells. Arterioscler Thromb Vasc Biol 1999;19:1623-1629.

48. Hahn AW, Jonas U, Bühler FR, Resink TJ: Activation of human peripheral monocytes by angiotensin ii. FEBS Lett 1994;347:178-180.

49. Tummala PE, Chen XL, Sundell CL, Laursen JB, Hammes CP, Alexander RW, Harrison DG, Medford RM: Angiotensin ii induces vascular cell adhesion molecule-1 expression in rat vasculature: A potential link between the renin-angiotensin system and atherosclerosis. Circulation 1999; 100:1223-1229.

50. Chen XL, Tummala PE, Olbrych MT, Alexander RW, Medford RM: Angiotensin ii induces monocyte chemoattractant protein-1 gene expression in rat vascular smooth muscle cells. Circ Res 1998;83:952-959.

51. Dzau VJ: Theodore cooper lecture: Tissue angiotensin and pathobiology of vascular disease: A unifying hypothesis. Hypertension 2001;37:1047-1052.

52. Becher UM, Endtmann C, Tiyerili V, Nickenig G, Werner N: Endothelial damage and regeneration: The role of the renin-angiotensin-aldosterone system. Curr Hypertens Rep 2011;13:86-92.

53. Rajagopalan S, Kurz S, Münzel T, Tarpey M, Freeman BA, Griendling KK, Harrison DG: Angiotensin ii-mediated hypertension in the rat increases vascular superoxide production via membrane nadh/nadph oxidase activation. Contribution to alterations of vasomotor tone. J Clin Invest 1996;97:1916-1923.

54. Wassmann S, Nickenig G: Pathophysiological regulation of the at1-receptor and implications for vascular disease. J Hypertens Suppl 2006;24:S15-21.

55. Qi G, Jia L, Li Y, Bian Y, Cheng J, Li H, Xiao C, Du $\mathrm{J}$ : Angiotensin ii infusion-induced inflammation, monocytic fibroblast precursor infiltration, and cardiac fibrosis are pressure dependent. Cardiovasc Toxicol 2011;11:157-167.

56. Gul R, Shawl AI, Kim SH, Kim UH: Co-operative interaction between reactive oxygen species and ca2+ signals contributes to angiotensin ii-induced hypertrophy in adult rat cardiomyocytes. Am J Physiol Heart Circ Physiol 2011

57. Geisterfer AA, Peach MJ, Owens GK: Angiotensin ii induces hypertrophy, not hyperplasia, of cultured rat aortic smooth muscle cells. Circ Res 1988;62:749-756.

58. Judkins CP, Diep H, Broughton BR, Mast AE, Hooker EU, Miller AA, Selemidis S, Dusting GJ, Sobey CG, Drummond GR: Direct evidence of a role for nox2 in superoxide production, reduced nitric oxide bioavailability, and early atherosclerotic plaque formation in apoe-/- mice. Am J Physiol Heart Circ Physiol 2010;298:H24-32.

59. Li Z, Iwai M, Wu L, Liu HW, Chen R, Jinno T, Suzuki J, Tsuda M, Gao XY, Okumura M, Cui TX, Horiuchi M: Fluvastatin enhances the inhibitory effects of a selective at1 receptor blocker, valsartan, on atherosclerosis. Hypertension 2004;44:758-763.

60. Förstermann U, Münzel T: Endothelial nitric oxide synthase in vascular disease: From marvel to menace. Circulation 2006;113:1708-1714.

61. Martinez FA: Aldosterone inhibition and cardiovascular protection: More important than it once appeared. Cardiovasc Drugs Ther 2010;24:345-350.

62. Cascella T, Radhakrishnan Y, Maile LA, Busby WH, Gollahon K, Colao A, Clemmons DR: Aldosterone enhances igf-i-mediated signaling and biological function in vascular smooth muscle cells. Endocrinology 2010;151:5851-5864.

63. Sherajee SJ, Fujita Y, Rafiq K, Nakano D, Mori H, Masaki T, Hara T, Kohno M, Nishiyama A, Hitomi H: Aldosterone induces vascular insulin resistance by increasing insulin-like growth factor-1 receptor and hybrid receptor. Arterioscler Thromb Vasc Biol 2012;32:257-263.

64. Marumo T, Uchimura H, Hayashi M, Hishikawa K, Fujita T: Aldosterone impairs bone marrow-derived progenitor cell formation. Hypertension 2006;48:490496.

65. Cooke JP, Singer AH, Tsao P, Zera P, Rowan RA, Billingham ME: Antiatherogenic effects of 1-arginine in the hypercholesterolemic rabbit. $J$ Clin Invest 1992;90:1168-1172.

66. Cook JL, Zhang Z, Re RN: In vitro evidence for an intracellular site of angiotensin action. Circ Res 2001;89:1138-1146.

67. Hunt MK, Ramos SP, Geary KM, Norling LL, Peach MJ, Gomez RA, Carey RM: Colocalization and release of angiotensin and renin in renal cortical cells. Am J Physiol 1992;263:F363-373.

68. Wang JM, Slembrouck D, Tan J, Arckens L, Leenen FH, Courtoy PJ, De Potter WP: Presence of cellular renin-angiotensin system in chromaffin cells of bovine adrenal medulla. Am J Physiol Heart Circ Physiol 2002;283:H1811-1818. 
69. Rajamohan SB, Raghuraman G, Prabhakar NR, Kumar GK: Nadph oxidase-derived h2o2 contributes to angiotensin ii-induced aldosterone synthesis in human and rat adrenal cortical cells. Antioxid Redox Signal 2012 70. Mansur SJ, Hage FG, Oparil S: Have the reninangiotensin-aldosterone system perturbations in cardiovascular disease been exhausted? Curr Cardiol Rep 2010;12:450-463.

71. Andersen K, Weinberger MH, Constance CM, Ali MA, Jin J, Prescott MF, Keefe DL: Comparative effects of aliskiren-based and ramipril-based therapy on the renin system during long-term (6 months) treatment and withdrawal in patients with hypertension. $J$ Renin Angiotensin Aldosterone Syst 2009;10:157-167.

72. Gossas T, Vrang L, Henderson I, Sedig S, Sahlberg C, Lindström E, Danielson UH: Aliskiren displays longlasting interactions with human renin. Naunyn Schmiedebergs Arch Pharmacol 2011

73. Yamauchi J, Shibagaki Y, Uehara K, Yasuda T, Kimura K: Aliskiren-associated acute kidney injury in a patient with pre-existing chronic kidney disease and dilated cardiomyopathy. Clin Exp Nephrol 2011

74. Kühnast S, van der Hoorn JW, van den Hoek AM, Havekes LM, Liau G, Jukema JW, Princen HM: Aliskiren inhibits atherosclerosis development and improves plaque stability in apoe*3leiden.Cetp transgenic mice with or without treatment with atorvastatin. J Hypertens 2012;30:107-116.

75. Schmieder RE, Martus P, Klingbeil A: Reversal of left ventricular hypertrophy in essential hypertension. A meta-analysis of randomized double-blind studies. JAMA 1996;275:1507-1513.

76. Shahin Y, Khan JA, Samuel N, Chetter I: Angiotensin converting enzyme inhibitors effect on endothelial dysfunction: A meta-analysis of randomised controlled trials. Atherosclerosis 2011;216:7-16.

77. Brunner H, Cockcroft JR, Deanfield J, Donald A, Ferrannini E, Halcox J, Kiowski W, Lüscher TF, Mancia G, Natali A, Oliver JJ, Pessina AC, Rizzoni D, Rossi GP, Salvetti A, Spieker LE, Taddei S, Webb DJ, Hypertension WGoEaEFotESo: Endothelial function and dysfunction. Part ii: Association with cardiovascular risk factors and diseases. A statement by the working group on endothelins and endothelial factors of the european society of hypertension. J Hypertens 2005;23:233-246. 78. Barrow SE, Dollery CT, Heavey DJ, Hickling NE, Ritter JM, Vial J: Effect of vasoactive peptides on prostacyclin synthesis in man. $\mathrm{Br} J$ Pharmacol 1986;87:243-247.

79. Mombouli JV, Illiano S, Nagao T, Scott-Burden T, Vanhoutte PM: Potentiation of endothelium-dependent relaxations to bradykinin by angiotensin $\mathrm{i}$ converting enzyme inhibitors in canine coronary artery involves both endothelium-derived relaxing and hyperpolarizing factors. Circ Res 1992;71:137-144.
80. Bomfim G, Dos Santos R, Oliveira MA, Giachini FR, Akamine E, Tostes RC, Fortes ZB, Webb RC, Carvalho $\mathrm{MH}$ : Toll like receptor 4 contributes to blood pressure regulation and vascular contraction in spontaneously hypertensive rat. Clin Sci (Lond) 2012 81. Sola S, Mir MQ, Cheema FA, Khan-Merchant N, Menon RG, Parthasarathy S, Khan BV: Irbesartan and lipoic acid improve endothelial function and reduce markers of inflammation in the metabolic syndrome: Results of the irbesartan and lipoic acid in endothelial dysfunction (island) study. Circulation 2005;111:343348.

82. Dandona P, Kumar V, Aljada A, Ghanim H, Syed T, Hofmayer D, Mohanty P, Tripathy D, Garg R: Angiotensin ii receptor blocker valsartan suppresses reactive oxygen species generation in leukocytes, nuclear factor-kappa $b$, in mononuclear cells of normal subjects: Evidence of an antiinflammatory action. $J$ Clin Endocrinol Metab 2003;88:4496-4501.

83. Kyotani Y, Zhao J, Tomita S, Nakayama H, Isosaki M, Uno M, Yoshizumi M: Olmesartan inhibits angiotensin ii-induced migration of vascular smooth muscle cells through src and mitogen-activated protein kinase pathways. J Pharmacol Sci 2010;113:161-168.

84. Min TQ, Zhu CJ, Xiang WX, Hui ZJ, Peng SY: Improvement in endothelial progenitor cells from peripheral blood by ramipril therapy in patients with stable coronary artery disease. Cardiovasc Drugs Ther 2004; 18:203-209.

85. Bahlmann FH, de Groot K, Mueller O, Hertel B, Haller H, Fliser D: Stimulation of endothelial progenitor cells: A new putative therapeutic effect of angiotensin ii receptor antagonists. Hypertension 2005;45:526-529.

86. Caprio M, Mammi C, Jaffe IZ, Zennaro MC, Aversa A, Mendelsohn ME, Fabbri A, Rosano GM: The mineralocorticoid receptor in endothelial physiology and disease: Novel concepts in the understanding of erectile dysfunction. Curr Pharm Des 2008;14:3749-3757.

87. McCurley A, Jaffe IZ: Mineralocorticoid receptors in vascular function and disease. Mol Cell Endocrinol 2011 88. Caprio M, Newfell BG, la Sala A, Baur W, Fabbri A, Rosano G, Mendelsohn ME, Jaffe IZ: Functional mineralocorticoid receptors in human vascular endothelial cells regulate intercellular adhesion molecule-1 expression and promote leukocyte adhesion. Circ Res 2008;102:1359-1367.

89. Thum T, Schmitter K, Fleissner F, Wiebking V, Dietrich B, Widder JD, Jazbutyte V, Hahner S, Ertl G, Bauersachs J: Impairment of endothelial progenitor cell function and vascularization capacity by aldosterone in mice and humans. Eur Heart J 2011;32:1275-1286.

90. Haznedaroglu IC, Oztürk MA: Towards the understanding of the local hematopoietic bone marrow renin-angiotensin system. Int $J$ Biochem Cell Biol 2003;35:867-880. 
91. Touyz RM, Schiffrin EL: Signal transduction mechanisms mediating the physiological and pathophysiological actions of angiotensin ii in vascular smooth muscle cells. Pharmacol Rev 2000;52:639-672.

92. Itoh H, Mukoyama M, Pratt RE, Gibbons GH, Dzau VJ: Multiple autocrine growth factors modulate vascular smooth muscle cell growth response to angiotensin ii. $J$ Clin Invest 1993;91:2268-2274.

93. Pollman MJ, Yamada T, Horiuchi M, Gibbons GH: Vasoactive substances regulate vascular smooth muscle cell apoptosis. Countervailing influences of nitric oxide and angiotensin ii. Circ Res 1996;79:748-756.

94. Park JB, Schiffrin EL: Small artery remodeling is the most prevalent (earliest?) form of target organ damage in mild essential hypertension. J Hypertens 2001;19:921930.

95. Oparil S, Haber E: The renin-angiotensin system (first of two parts). N Engl J Med 1974;291:389-401.

96. Oparil S, Haber E: The renin-angiotensin system (second of two parts). N Engl J Med 1974;291:446-457.

97. Morishita R, Gibbons GH, Tomita N, Zhang L, Kaneda Y, Ogihara T, Dzau VJ: Antisense oligodeoxynucleotide inhibition of vascular angiotensinconverting enzyme expression attenuates neointimal formation: Evidence for tissue angiotensin-converting enzyme function. Arterioscler Thromb Vasc Biol 2000;20:915-922.

98. Watkins SJ, Borthwick GM, Oakenfull R, Robson A, Arthur HM: Angiotensin ii-induced cardiomyocyte hypertrophy in vitro is tak1-dependent and $\operatorname{smad} 2 / 3$ independent. Hypertens Res 2011

99. Maejima Y, Okada H, Haraguchi G, Onai Y, Kosuge H, Suzuki J, Isobe M: Telmisartan, a unique arb, improves left ventricular remodeling of infarcted heart by activating ppar gamma. Lab Invest 2011;91:932-944.

100. Dzau VJ, Bernstein K, Celermajer D, Cohen J, Dahlöf B, Deanfield J, Diez J, Drexler H, Ferrari R, van Gilst W, Hansson L, Hornig B, Husain A, Johnston C, Lazar H, Lonn E, Lüscher T, Mancini J, Mimran A, Pepine C, Rabelink T, Remme W, Ruilope L, Ruzicka M, Schunkert H, Swedberg K, Unger T, Vaughan D, Weber M, Working Group on Tissue Angiotensinconverting enzyme ItSoCP: The relevance of tissue angiotensin-converting enzyme: Manifestations in mechanistic and endpoint data. Am $J$ Cardiol 2001;88:1L-20L

101. Yamada T, Kondo T, Numaguchi Y, Tsuzuki M, Matsubara T, Manabe I, Sata M, Nagai R, Murohara T: Angiotensin ii receptor blocker inhibits neointimal hyperplasia through regulation of smooth muscle-like progenitor cells. Arterioscler Thromb Vasc Biol 2007;27:2363-2369.
102. Powell JS, Clozel JP, Müller RK, Kuhn H, Hefti F, Hosang M, Baumgartner HR: Inhibitors of angiotensinconverting enzyme prevent myointimal proliferation after vascular injury. Science 1989;245:186-188.

103. Yoshida O, Hirayama H, Nanasato M, Watanabe T, Murohara T: The angiotensin ii receptor blocker candesartan cilexetil reduces neointima proliferation after coronary stent implantation: A prospective randomized study under intravascular ultrasound guidance. Am Heart J 2005;149:e2.

104. Peters S, Götting B, Trümmel M, Rust H, Brattström A: Valsartan for prevention of restenosis after stenting of type b2/c lesions: The val-prest trial. $J$ Invasive Cardiol 2001;13:93-97.

105. Kosuge H, Ishihara T, Haraguchi G, Maejima Y, Okada H, Saiki H, Suzuki J, Isobe M: Treatment with telmisartan attenuates graft arteriosclerosis in murine cardiac allografts. J Heart Lung Transplant 2010;29:562567.

106. Gómez-Garre D, Martín-Ventura JL, Granados R, Sancho T, Torres R, Ruano M, et al: Losartan improves resistance artery lesions and prevents ctgf and tgf-beta production in mild hypertensive patients. Kidney Int 2006;69:1237-1244.

107. Sonoda M, Aoyagi T, Takenaka K, Uno K, Nagai $\mathrm{R}$ : A one-year study of the antiatherosclerotic effect of the angiotensin-ii receptor blocker losartan in hypertensive patients. A comparison with angiotensionconverting enzyme inhibitors. Int Heart J 2008;49:95103.

108. Brilla CG, Matsubara LS, Weber KT: Antifibrotic effects of spironolactone in preventing myocardial fibrosis in systemic arterial hypertension. Am J Cardiol 1993;71:12A-16A.

109. Sadoshima J, Izumo S. Molecular characterization of angiotensin II-induced hypertrophy of cardiac myocytes and hypeplasia of cardiac fibroblasts: critical role of the AT1 receptor subtype. Circ Res 1993;73:413423.

110. Kawano H, Cody RJ, Graf K et al. Angiotensin II enhances integrin and alpha-actinin expression in adult rat cardiac fibroblasts. Hypertension $2000 \mathrm{Jan} ; 35(1 \mathrm{Pt}$ 2):273-9.

DISCOVERIES is a peer-reviewed, open access, online, multidisciplinary and integrative journal, publishing high impact and innovative manuscripts from all areas related to MEDICINE, BIOLOGY and CHEMISTRY; C 2013, Applied Systems 